\title{
Light absorption of Isochrysis galbana (Prymnesiophyceae) under a day-night cycle with ultraviolet radiation
}

\author{
Nobuaki Ohi ${ }^{1,2, *}$, Akemi Mizobuchi ${ }^{1}$, Satoru Taguchi ${ }^{1}$ \\ ${ }^{1}$ Department of Environmental Engineering for Symbiosis, Soka University, 1-236 Tangi-cho, Hachiouji, \\ Tokyo 192-8577, Japan \\ ${ }^{2}$ Present address: National Aeronautics and Space Administration, Hydrospheric and Biospheric Sciences Laboratory, \\ Goddard Space Flight Center, Wallops Island, Virginia 23337, USA
}

\begin{abstract}
Diel variation in chlorophyll $a$-specific absorption coefficients, $a^{*}{ }_{\mathrm{ph}}(\lambda), \mathrm{m}^{2}(\mathrm{mg} \mathrm{chl} a)^{-1}$, was examined to study the effect of ultraviolet radiation (UVR) on $a^{*}{ }_{p h}(\lambda)$ of the prymnesiophycean Isochrysis galbana (Parke). A continuous culture was exposed for $2 \mathrm{wk}$ to a $12 \mathrm{~h}$ light:12 h dark cycle of photosynthetically available radiation (PAR) supplemented with UVR. Photosynthetic and photoprotective pigments as well as cell density and diameter were also determined every $2 \mathrm{~h}$ for $2 \mathrm{~d}$ to confirm the periodicity of $a^{*} \mathrm{ph}(\lambda)$. A distinct diel variation was observed, with maxima toward the end of light periods and minima toward the end of dark periods. The magnitude of diel variation in $a^{*}{ }^{*}(440)$ and $a^{*}{ }^{*}(676)$ was 14 and $6.6 \%$, respectively. To reconstruct the absorption coefficient, the absorption efficiency factors $Q_{a}(\lambda)$, were determined using intracellular chl a concentration, cell diameter, and chl $a$-specific absorption coefficients after solubilization on Triton $\mathrm{X}, a^{*}{ }_{\mathrm{TX}}(\lambda)$. The main source of diel variation for $Q_{a}(\lambda)$ appears to be $a^{*}{ }_{T X}(\lambda)$. Diel variation in the absorption ratio of photoprotective pigments to chl $a$ was observed to be more significant than that for the absorption ratio of other photosynthetic pigments to chl $a$. The diel variations in $a^{*}{ }_{\mathrm{ph}}(\lambda)$ were primarily caused by changes in pigmentation of photoprotective pigments due to UVR.
\end{abstract}

KEY WORDS: Absorption · Diel cycle $\cdot$ Optical properties $\cdot$ Pigmentation $\cdot$ UV

\section{INTRODUCTION}

Studies on diel variations in optical properties have focused on the attenuation, scattering and absorption coefficients (Siegel et al. 1989, Dickey et al. 1990, Hamilton et al. 1990, Kroon et al. 1992, Stramska \& Dickey 1992, Stramski \& Reynolds 1993, Gardner et al. 1995, Stramski et al. 1995, DuRand \& Olson 1996, 1998). Diel variations in the chlorophyll (chl) $a$-specific absorption coefficient, $a^{*}{ }^{*}(\lambda)$ (list of notations is provided in Table 1), have also sometimes been observed (Stramski \& Reynolds 1993, Stramski et al. 1995). Ohi et al. (2002) showed recently that the coefficient of variation $(\mathrm{CV})$ of diel variability in $a^{*}{ }_{\mathrm{ph}}(675)$ for the prymnesiophycean Isochrysis galbana was $9.3 \%$ under $500 \mu \mathrm{mol}$ photons $\mathrm{m}^{-2} \mathrm{~s}^{-1}$ over a 12:12 h light-dark cycle. Diel variation in $a^{*}{ }_{p h}(\lambda)$ can result from a combination of influences on pigmentation that are controlled by photoprotective and photosynthetic pigments (e.g. Sosik \& Mitchell 1994) and pigment-packaging effects that vary with cell diameter and intracellular chl a concentration (e.g. Morel \& Bricaud 1981). Distinct diel variations in $a^{*}{ }_{\mathrm{ph}}(\lambda)$ observed for I. galbana with maxima toward the end of dark periods and minima toward the end of light periods under $500 \mu \mathrm{mol}$ photons $\mathrm{m}^{-2} \mathrm{~s}^{-1}$ were due to the package effect, but not the pigmentation (Ohi et al. 2002). However, diel variation in $a^{*}{ }_{\mathrm{ph}}(\lambda)$ has not been reported under illumination that includes UVR. Knowledge of the diel variation in $a^{*}$ ph $(\lambda)$ is important for determining the optical properties of phytoplankton and could contribute to interpretations of absorption properties 
and estimates of primary productivity under illumination that includes UVR encountered in the surface layer of the ocean.

The efficiency factor for absorption, $Q_{a}(\lambda)$, is the ratio of the energy absorbed within a cell to the energy incident on its geometrical cross section. $Q_{a}(\lambda)$ and $a^{*}{ }_{\mathrm{ph}}$ $(\lambda)$ can be reconstructed from the intracellular chl $a$ concentration, cell diameter and the unpackaged chl a-specific absorption coefficients after solubilization in Triton X. Such reconstruction allows us to determine whether the observed absorption properties are fully consistent with reconstructed $a^{*}$ ph $(\lambda)$, and predictable from cell characteristics. This reconstruction is also aimed at determining the respective contributions of factors responsible for changes in the absorption properties of phytoplankton cells.

In the experiments reported here on diel variations in $a^{*}{ }_{p h}(\lambda)$ of a phytoplankton species, we chose the prymnesiophycean Isochrysis galbana because similarly-sized nanoplankton cells are known to contribute significantly to the bulk optical properties of openocean waters (DuRand \& Olson 1996). The aims of this study were therefore (1) to describe the diel variability in light-absorption properties of $I$. galbana at $500 \mu \mathrm{mol}$ photons $\mathrm{m}^{-2} \mathrm{~s}^{-1}$ in the presence of UVR; (2) to differ-

Table 1. Definition of mathematical symbols and associated units used in present paper. -: dimensionless

\begin{tabular}{|c|c|c|}
\hline Symbol & Definition & Units \\
\hline $\mathrm{CV}$ & Coefficient of variation throughout a diel cycle & $\%$ \\
\hline$\lambda$ & Wavelength & $\mathrm{nm}$ \\
\hline $\mathrm{OD}(\lambda)$ & Optical density at a given wavelength & - \\
\hline$[\mathrm{chl} a]$ & Chlorophyll a concentration & $\mathrm{mg} \mathrm{m}^{-3}$ \\
\hline$a_{\mathrm{ph}}(\lambda)$ & Absorption coefficient of phytoplankton & $\mathrm{m}^{-1}$ \\
\hline$a_{\mathrm{TX}}(\lambda)$ & Absorption coefficient after solubilization in Triton X-100 & $\mathrm{m}^{-1}$ \\
\hline$a_{\text {rec }}(\lambda)$ & Reconstructed absorption coefficient of phytoplankton & $\mathrm{m}^{-1}$ \\
\hline$a_{\text {total }}(\lambda)$ & Absorption coefficient of total pigments & $\mathrm{m}^{-1}$ \\
\hline$a_{\text {pig }}(\lambda)$ & Absorption coefficient of pigment $p$ & $\mathrm{~m}^{-1}$ \\
\hline$a_{\mathrm{chl} a}(\lambda)$ & Absorption coefficient of chl $a$ & $\mathrm{~m}^{-1}$ \\
\hline$a_{\mathrm{chl} c}(\lambda)$ & Absorption coefficient of $\mathrm{chl} C_{1+2}$ & $\mathrm{~m}^{-1}$ \\
\hline$a_{\text {fuco }}(\lambda)$ & Absorption coefficient of fucoxanthin & $\mathrm{m}^{-1}$ \\
\hline$a_{\mathrm{DD}+\mathrm{DT}}(\lambda)$ & Absorption coefficient of diadinoxanthin plus diatoxanthin & $\mathrm{m}^{-1}$ \\
\hline$a_{\beta, \beta-\text { carotene }}(\lambda)$ & Absorption coefficient of $\beta, \beta$-carotene & $\mathrm{m}^{-1}$ \\
\hline$a_{i, p}^{*}(\lambda)$ & Weight-specific absorption coefficient of pigment $p$ & $\mathrm{~m}^{2}(\mathrm{mg} \mathrm{chl} \mathrm{a})^{-1}$ \\
\hline$a^{*}{ }_{p h}(\lambda)$ & Chlorophyll $a$-specific absorption coefficient & $\mathrm{m}^{2}(\mathrm{mg} \operatorname{chl} a)^{-1}$ \\
\hline$a^{*} \mathrm{TX}(\lambda)$ & $\begin{array}{l}\text { Chlorophyll a-specific absorption coefficient } \\
\text { after solubilization in Triton X-100 }\end{array}$ & $\mathrm{m}^{2}(\mathrm{mg} \mathrm{chl} a)^{-1}$ \\
\hline$a_{\text {rec }}^{*}(\lambda)$ & Reconstructed chl a-specific absorption coefficient & $\mathrm{m}^{2}(\mathrm{mg} \mathrm{chl} \mathrm{a})^{-1}$ \\
\hline$a_{\mathrm{Cm}}(\lambda)$ & Absorption coefficient of cell material & $\mathrm{m}^{-1}$ \\
\hline $\mathrm{N}$ & Number of cells & cells \\
\hline $\mathrm{V}$ & Volume of suspension & $\mathrm{m}^{3}$ \\
\hline$d$ & Mean cell diameter of population & $\mu \mathrm{m}$ \\
\hline$Q_{a}(\lambda)$ & Efficiency factor for absorption & - \\
\hline$Q_{a}{ }^{*}(\lambda)$ & Package-effect index & - \\
\hline$\rho^{\prime}$ & Optical thickness along the particle diameter & - \\
\hline$C_{i, p}$ & Intracellular concentration of pigment $p$ & $\mathrm{~kg} \mathrm{~m}^{-3}$ \\
\hline$C_{\text {chl a }}$ & Intracellular chl a concentration & $\mathrm{kg} \mathrm{m}^{-3}$ \\
\hline
\end{tabular}

entiate between package effects and pigmentation effects on the diel variation in $a^{*}{ }_{\mathrm{ph}}(\lambda)$ under illumination that includes UVR; (3) to reconstruct the $a^{*}{ }_{\mathrm{ph}}(\lambda)$ spectra from the cell characteristics and to determine how the package effect and pigmentation effect contribute to the diel variations in $a^{*}{ }_{\mathrm{ph}}(\lambda)$ under the presence of UVR.

\section{MATERIALS AND METHODS}

Culture procedure and sampling. Culture conditions and experimental procedures have been described in detail by Ohi et al. (2002, 2003). Prymnesiophyceae Isochrysis galbana Parke (NEPCC 633) were obtained from The North East Pacific Culture Collection (NEPCC) at the University of British Columbia, Canada. I. galbana was grown on a $12 \mathrm{~h}$ light:12 h dark cycle at $25^{\circ} \mathrm{C}$ in a $1.4 \mathrm{l}$, quartz, culture vessel in seawater enriched with f/2 medium (Guillard \& Ryther 1962). Careful axenic techniques were used to minimize bacterial contamination in the maintenance and growth of the culture. Visible radiation was from National cool-white fluorescent tubes (FL30S·EX-N) providing a quantum scalar irradiance of $500 \mu \mathrm{mol}$ photons $\mathrm{m}^{-2} \mathrm{~s}^{-1}$ (photosynthetically available radiation, PAR, 400 to $700 \mathrm{~nm}$ ) measured by a Biospherical Instrument QSL-100 $4 \pi$ sensor immersed in a waterfilled culture vessel. Ultraviolet radiation (UVR), predominantly UV-B, was from Toshiba ultraviolet tubes (FL202·E) (see Fig. 2 in Taira et al. 2004) covered with acetate film $1<290 \mathrm{~nm}$ cutoff, Polymer Plastics Corporation) (See Fig. 1 in Taira et al. 2004). The acetate film was changed every $5 \mathrm{~d}$. The UVR dose-rate was measured by a Biospherical Instrument PUV-510 surface radiometer. The instrument provided UVR measurements at 308, 320, 340 and $380 \mathrm{~nm}$. The photon-fluence density at $280 \mathrm{~nm}$ was assumed to be $0 \mathrm{~mW} \mathrm{\textrm {m } ^ { - 2 }}$ $\mathrm{nm}^{-1}$, since the FL202E UV lamp does not emit light $<280$ nm (see Fig. 2 in Taira et al. 2004). In order to 
obtain absolute values of UVB, light intensities were integrated from 280 to $320 \mathrm{~nm}$ for the $>280 \mathrm{~nm}$ treatment. UVA intensity was also integrated from 320 to $400 \mathrm{~nm}$. Biologically effective irradiances for different treatments were determined as described by Smith \& Baker (1979) and Smith et al. (1980) using the DNA weighting function of Stelow (1974), the generalized plant function of Caldwell (1971) and the chloroplast photoinhibition function of Jones \& Kok (1966). Weightings and UV irradiances for intermediate wavelengths were calculated by linear interpolation.

The culture was operated in a continuous turbidostat with the dilution rate dictated by the growth rate of cells. The culture was acclimated to PAR for $11 \mathrm{~d}$ and PAR + UVR for $9 \mathrm{~d}$. Cells were kept in suspension by a combination of continuous stirring and bubbling sterile air.

At each sampling, fresh media were added via a peristaltic pump to maintain relatively constant cell density (no./vol, N/V) within the optically thin suspension. The N/V averaged $4.3 \times 10^{12}$ cells m$^{-3}$ throughout the experiment. Separate duplicate sampling were initiated for the determination of absorption coefficient and pigments every $2 \mathrm{~h}$ for $48 \mathrm{~h}$. These samples were filtered onto $25 \mathrm{~mm}$ GF/F glass-fiber filters (Whatman) under pressure lower than $100 \mathrm{~mm} \mathrm{Hg}$.

Cell number and diameter. Samples were preserved by adding $10 \%$ neutralized formaldehyde to obtain a $0.2 \%$ final concentration, and stored in the dark at $4^{\circ} \mathrm{C}$. We confirmed that such treatment for this species induced only minor changes in cell diameter $(<5 \%)$. Cell numbers were measured under a microscope with a hemacytometer (Bright-Line, Erma). Every $2 \mathrm{~h}$, growth rate was calculated from the logarithm variations in cell abundance and dilution rate. Spherical cell diameters of 75 cells were measured under the microscope with an ocular ruler at $1000 \times$ magnification. The average cell volume was calculated from the average cell diameter, $d$, under the assumption that all cells were spherical.

Absorption coefficients. Optical densities, $\mathrm{OD}(\lambda)$, of suspensions were determined with a Shimadzu UV2450 spectrophotometer equipped with an integrating sphere, with reference to a filtrate of the suspension (Whatman GF/F glass-fiber filter). OD $(\lambda)$ was measured by placing the cuvettes at the entrance to an integrating sphere that minimized losses due to lightscattering. Absorption coefficients, $a_{\mathrm{ph}}(\lambda)$, were obtained as follows (van de Hulst 1957):

$$
a_{\mathrm{ph}}(\lambda)=2.3 \mathrm{OD}(\lambda) / \mathrm{r}
$$

where $r(=0.01 \mathrm{~m})$ is the pathlength of the cuvette. Spectral values of the absorption coefficient were recorded every $1 \mathrm{~nm}$ from 350 to $750 \mathrm{~nm}$. All spectra were set to zero at $750 \mathrm{~nm}$ to minimize differences between sample and reference, assuming lack of ab- sorption by particles at $750 \mathrm{~nm}$ (Babin \& Stramski 2002). The spectral absorption at all other wavelengths was also corrected for that offset at $750 \mathrm{~nm}$. The chl aspecific absorption coefficients $a^{*}{ }_{\mathrm{ph}}(\lambda)$ were obtained from the absorption coefficients $a_{\mathrm{ph}}(\lambda)$, according to:

$$
a^{*}{ }_{\mathrm{ph}}(\lambda)=a_{\mathrm{ph}}(\lambda) /[\mathrm{chl} a]
$$

where [chl a] is chlorophyll a concentration.

To differentiate between package and pigmentation effects on the diel variation in $a^{*}{ }_{p h}(\lambda)$, cells were solubilized in the detergent Triton X-100 at a final concentration of $0.5 \%$ (in volume) with subsequent sonication as recommended by Berner et al. (1989). The Triton extracts were centrifuged, and spectral absorption $a_{\mathrm{TX}}(\lambda)$ was determined on these solubilized cells with $0.5 \%$ Triton X-100 in filtered seawater as reference. These chl a-specific absorption coefficients for samples solubilized in Triton X-100, $a^{*}{ }_{\mathrm{TX}}(\lambda)$ were calculated as described for $a^{*}{ }_{p h}(\lambda)$. Because the Triton $X$ removes the effect of packaging pigments from the cells and chloroplasts, any changes in $a^{*} \mathrm{TX}(\lambda)$ are due only to changes in the pigmentation. The Triton X method involves spectral shifts in the wavelengths of peak absorption compared to in vivo absorption (Sosik \& Mitchell 1991). In fact, we have observed shifts toward shorter wavelengths of $1 \mathrm{~nm}$ at the blue peak and $8 \mathrm{~nm}$ at the red peak. To compensate for these shifts, when using $a^{*}{ }_{\text {TX }}(\lambda)$ in calculations or comparison with $a^{*}{ }_{\mathrm{ph}}(\lambda)$, we shifted the spectra by $1 \mathrm{~nm}$ for wavelengths of 350 to $557 \mathrm{~nm}$ and $8 \mathrm{~nm}$ for wavelengths of 551 to $750 \mathrm{~nm}$. The region between 551 and $557 \mathrm{~nm}$ was repeated to prevent introduction of a gap in the spectra; values were relatively low and uniform at these wavelengths, so this treatment did not distort the spectra.

Pigments. The filtered samples were sonificated for $10 \mathrm{~min}$ in $10 \mathrm{ml}$ of $90 \%$ acetone, and extracted for $24 \mathrm{~h}$ at $4^{\circ} \mathrm{C}$. Following extraction, pigment samples were centrifuged for $5 \mathrm{~min}$ to remove cellular debris. Pigment analysis was carried out by HPLC (System Gold, Beckman) using the solvent gradient-system described by Head \& Horne (1993). Identified pigments were chl $C_{1+2}$, fucoxanthin, diadinoxanthin, diatoxanthin, chl $a$ and $\beta, \beta$-carotene. Integrated peak areas were quantified with external standards obtained from the 'International Agency for ${ }^{14} \mathrm{C}$ Determination', Denmark.

Reconstruction of absorption-efficiency factors from cell characteristics and package effect. Cells are assumed to be spherical and homogeneous with respect to the refractive index when the anomalous diffraction approximation is made (van de Hulst 1957). The reconstructed chl a-specific absorption coefficients $a^{*}$ rec $(\lambda)$ can be estimated by dividing the reconstructed absorption coefficients $a_{\text {rec }}(\lambda)$ by [chl $\left.a\right]$. The $a_{\text {rec }}(\lambda)$ can be estimated using the number of cells, $\mathrm{N}$, in a volume of the 
suspension, $\mathrm{V}$, the efficiency factors for absorption, $Q_{a}(\lambda)$ and the geometrical cross section determined by spherical cell diameter $d$ (Morel \& Bricaud 1981):

$$
a_{\text {rec }}(\lambda)=\mathrm{N} / \mathrm{V} \cdot Q_{a}(\lambda) \cdot(\pi / 4) d^{2}
$$

The $Q_{a}(\lambda)$ for a single cell, i.e. the ratio of absorbed to energy incident on the geometrical cross section of the cell, can be estimated (van de Hulst 1957) as:

$$
\begin{aligned}
Q_{a}(\lambda)= & 1+2 \exp \left[-\rho^{\prime}(\lambda)\right] / \rho^{\prime}(\lambda) \\
& +2\left\{\exp \left[-\rho^{\prime}(\lambda)\right]-1\right\} /\left[\rho^{\prime}(\lambda)^{2}\right]
\end{aligned}
$$

where $\rho^{\prime}(\lambda)$ is the dimensionless optical thickness of the particles. The $\rho^{\prime}(\lambda)$ were here computed from $a^{*}{ }_{\mathrm{TX}}(\lambda)$ (Sosik \& Mitchell 1991), intracellular chl a concentration, $C_{\mathrm{chl}}$, and $d$ according to:

$$
\rho^{\prime}(\lambda)=a^{*} \operatorname{TX}(\lambda) \cdot C_{\mathrm{Chl} a} \cdot d
$$

where $C_{\mathrm{chl} a}$ is the ratio of [chl a] to the product of cell volume and cell density:

$$
C_{\text {chl } a}=[\mathrm{chl} a] /\left[(\pi / 6) d^{3} \cdot \mathrm{N} / \mathrm{V}\right]
$$

The intracellular concentrations of various pigments $p$, $C_{i, p}$, were computed from each pigment, $p$, using Eq. (6). The fractional reduction of absorption due to the package effect $Q_{a}{ }^{*}(\lambda)$ is computed (Morel \& Bricaud 1981) as:

$$
Q_{a}{ }^{*}(\lambda)=(3 / 2) \cdot Q_{a}{ }^{*}(\lambda) / \rho^{\prime}(\lambda)
$$

Contribution of pigmentation to $\boldsymbol{a}^{*}{ }_{\mathrm{ph}}(\boldsymbol{\lambda})$. We examined pigmentation, which affected the magnitude of diel variation in $a^{*}{ }_{\mathrm{ph}}(440)$. The contribution of each pigment to the variation in $a^{*}{ }_{\mathrm{ph}}(\lambda)$ is equal to the product of the intracellular concentrations of various pigments, $C_{i, p}$, and the pigment-specific absorption coefficients. Absorption coefficients of various pigments, $a_{\text {pig }}(\lambda)$, were related to absorption coefficients of total pigments, $a_{\text {total }}(\lambda)$, according to:

$$
a_{\text {pig }}(\lambda) / a_{\text {total }}(\lambda)=\left[c_{i, p} \cdot a^{*}{ }_{i, p}(\lambda)\right] /\left[\sum_{i=1}^{\mathrm{n}} C_{i, p} \cdot a^{*}{ }_{i, p}(\lambda)\right]
$$

where the value for the weight-specific absorption coefficient of pigment $p, a^{*}{ }_{i, p}(\lambda)$, was the weight-specific absorption coefficient proposed by Fujiki \& Taguchi (2001). This technique does not take into account pigment-packaging effects, but resolves issues regarding spectral shape and molar absorption coefficients. Despite these problems, the method allowed us to assess the relative importance of pigmentation to diel variation in $a^{*}{ }_{p h}(\lambda)$.

Mathematical and statistical analysis. The periodicity of the rhythm was analyzed by a modified function of the cosine function (Halberg et al. 1978, Kieding et al. 1984) as:

$$
Y=A+B \sin (\mathrm{t} \pi / 12)+C \cos (\mathrm{t} \pi / 12)
$$

where $Y$ is an estimate of a diel variable [e.g. $a^{*}{ }_{p h}(\lambda)$, cell diameter, etc.], $A$ is the average of the diel vari- able, $t$ is time in hours. $B$ is the amplitude of the sine function and $C$ is the amplitude of the cosine function; thus, the amplitude of the rhythm is calculated as $\left(B^{2}+C^{2}\right)^{1 / 2}$. A linear least-squares regression analysis was used to test the degree of fit of the estimated value to the observed value.

The magnitude of diel variation (\%) for each variable was calculated as:

Magnitude of diel variation $=|\max -\min | / \min \times 100$ (10) where max is $A+\left(B^{2}+C^{2}\right)^{1 / 2}$ and min is $A-\left(B^{2}+C^{2}\right)^{1 / 2}$.

\section{RESULTS}

Biologically weighted UV irradiances $(280$ to $400 \mathrm{~nm}$ ) for the biological weighting function tabulated by Smith et al. (1980) were $2.56 \mathrm{~mW} \mathrm{~m}^{-2}$ for DNA, $7.65 \mathrm{~mW} \mathrm{~m}^{-2}$ for plant and $46.78 \mathrm{~mW} \mathrm{~m}^{-2}$ for photoinhibition, respectively. Unweighted UVB (280 to $320 \mathrm{~nm}$ ) and UV (280 to $400 \mathrm{~nm}$ ) irradiances were 52.77 and $157.31 \mathrm{~mW} \mathrm{~m}^{-2}$, respectively. UV irradiances for the acetate film filtered FL202·E UVR lamps weighting by the photoinhibition of photosynthesis function were over 18 times greater for PAR+UVR culture (46.78 $\mathrm{mW} \mathrm{m}^{-2}, 290$ to $400 \mathrm{~nm}$ ) than when weighted by the DNA weighting function $(2.56 \mathrm{~mW}$ $\mathrm{m}^{-2}, 290$ to $\left.400 \mathrm{~nm}\right)$. Unweighted irradiances of UVR and UVB were $157.31 \mathrm{~mW} \mathrm{~m}^{-2}$ at 290 to $400 \mathrm{~nm}$ and $52.76 \mathrm{~mW} \mathrm{~m}^{-2}$ at 290 to $320 \mathrm{~nm}$, respectively, for the $\mathrm{PAR}+\mathrm{UVR}$ culture. Additionally, the unweighted UVB irradiance $\left(52.76 \mathrm{~mW} \mathrm{~m}^{-2}\right)$ PAR (500 $\mu \mathrm{mol} \mathrm{m} \mathrm{m}^{-2}$ $\mathrm{s}^{-1}$ ) ratio for the PAR + UVR culture was 0.1055. Total UVB exposures and the UVB/PAR ratio are similar or low for these experiments compared to daily average UVB irradiance $\left(51.19 \mathrm{~mW} \mathrm{~m}^{-2}\right.$ ) and the UVB/PAR ratio $(0.3385)$ at $10 \mathrm{~m}$ in the Florida Keys (see Table 1 in Lesser 2000). However, the UVB component was $33 \%$ of the total UVR irradiance, and was caused by the spectral shift of fluorescent tubes into the UVB portion of the spectrum. These unnatural radiation regimes were used here, as in other studies (e.g. Lesser et al. 2002), to examine the mechanistic effects on several processes related to the light absorption of photoinhibition for photosynthesis, and not spectral sensitivity as described above for the biological weighting-function calculations.

Mean growth rate calculated over a diel cycle (48 h) was $0.36 \mathrm{~d}^{-1}$ under PAR + UVR and $0.31 \mathrm{~d}^{-1}$ under $500 \mu \mathrm{mol} \mathrm{m}{ }^{-2} \mathrm{~s}^{-1}$ PAR alone, respectively. Growth rates were not significantly different under PAR + UVR and PAR alone (Welch's $t$-test; $\mathrm{p}>0.05$ ).

The $a^{*}{ }_{p h}(\lambda)$ spectra throughout a diel cycle exhibited absorption bands corresponding to chl a at around 440 and $676 \mathrm{~nm}$, bands corresponding to accessory pig- 
ments at around 460 and $490 \mathrm{~nm}$, and spectral regions of relatively weak absorption between 586 and $635 \mathrm{~nm}$ (Fig. 1). The significant 1:1 linear relationship between all measured data in the present study (Table 2) and the data estimated by Eq. (9) indicate distinct diel variation. Distinct diel variations in measured $a^{*}{ }_{\mathrm{ph}}(\lambda)$ were observed for the red-absorption maximum at $676 \mathrm{~nm}$ and the blue-absorption maximum at $440 \mathrm{~nm}$, with maxima toward the end of light periods and minima toward the end of dark periods ( $p<0.01$ at 440 and $676 \mathrm{~nm}$ ) (Fig. 2). The magnitude of diel variation in $a^{*}{ }_{p h}(\lambda)$ was $6.6 \%$ at $676 \mathrm{~nm}$ and $14 \%$ at $440 \mathrm{~nm}$, respectively (Table 2).

In detergent-solubilized samples, the absorption peak shifted toward shorter wavelengths of $1 \mathrm{~nm}$ at the blue peak and $8 \mathrm{~nm}$ at the red peak. The spectral values of $a^{*}{ }_{\mathrm{TX}}(\lambda)$ are presented following adjustment (Fig. 1). Distinct diel variations in $a^{*} \mathrm{TX}(\lambda)$ were also present, with maxima toward the end of light periods and minima toward the end of dark periods ( $p<0.05$ at 676 and $440 \mathrm{~nm}$ ) (Fig. 2). The magnitude of diel variation in $a^{*} \operatorname{TX}(\lambda)$ was $7.9 \%$ at $676 \mathrm{~nm}$ and $15 \%$ at $440 \mathrm{~nm}$, respectively (Table 2 ).
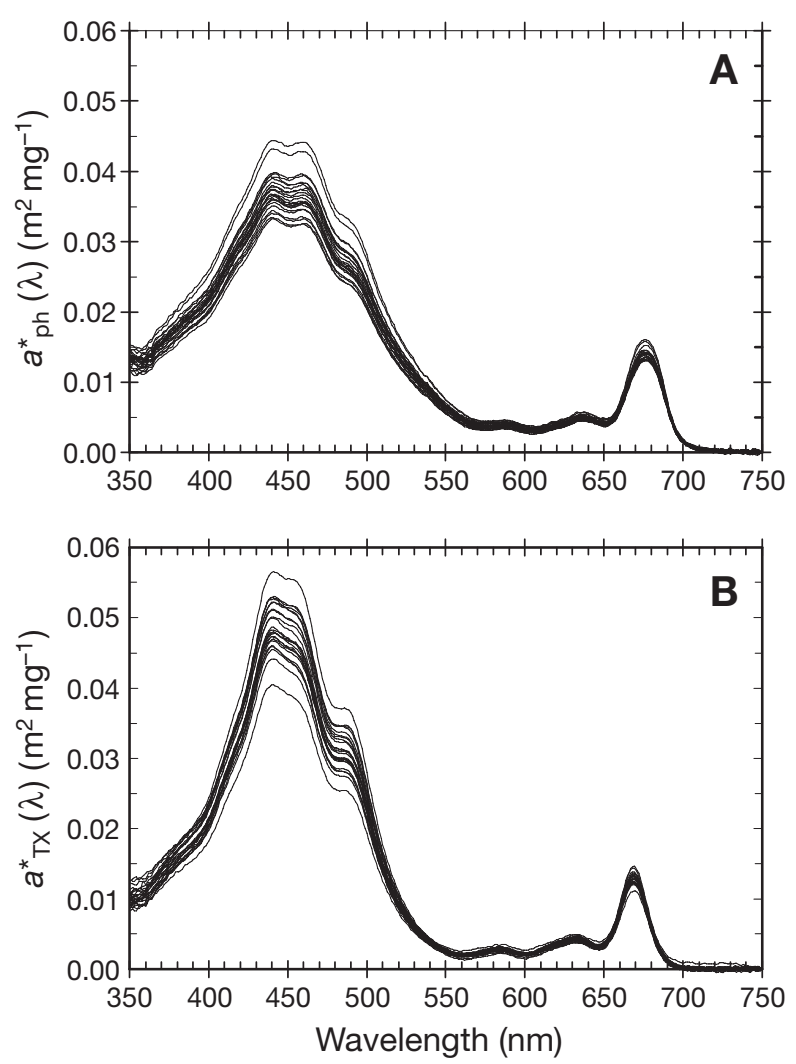

Fig. 1. Isochrysis galbana. Diel variations in spectral values of (A) chlorophyll $a$-specific absorption coefficients, $a^{*}{ }_{\mathrm{ph}}(\lambda)$, and (B) $a^{*}{ }_{\mathrm{ph}}(\lambda)$ after solubilization in $0.5 \%$ Triton X-100, $a^{*}{ }_{\mathrm{TX}}(\lambda)$. Each graph comprises 24 spectra determined throughout experiments
A distinct diel variation was observed for [chl a], with maxima toward the end of dark periods and minima toward the end of light periods $(\mathrm{p}<0.001)$. The magnitude of diel variation was $-28 \%$ for [ $\mathrm{chl} \mathrm{a}$ ] (minus sign of the magnitude of diel variation indicates decrease during the light periods) (Table 2). A distinct diel variation was not observed for N/V ( $p>0.05)$. The coefficient of variation $(\mathrm{CV})$ throughout a diel cycle was $9.9 \%$ for N/V; $d$ exhibited a distinct diel variation, with maxima toward the end of light periods and minima toward the end of dark periods ( $p<0.001)$ (Fig. 3). The magnitude of diel variation in $d$ was $7.7 \%$ (Table 2 ). A distinct diel variation was obtained for $C_{\mathrm{chl} a}$, with maxima toward the end of dark periods and minima toward the end of light periods ( $p<0.001)$. The magnitude of diel variation in $C_{\mathrm{chl}}$ a was $-33 \%$ (minus sign of the magnitude of diel variation indicates decrease during the light periods).

The predominant pigments found in this study are in agreement with the previous findings of Zapata \& Garrido (1997). Distinct diel variations were observed for the fucoxanthin/chl $a$, chl $C_{1+2} / \mathrm{chl} a$ and (diadinoxanthin plus diatoxanthin)/chl a ratios, with maxima
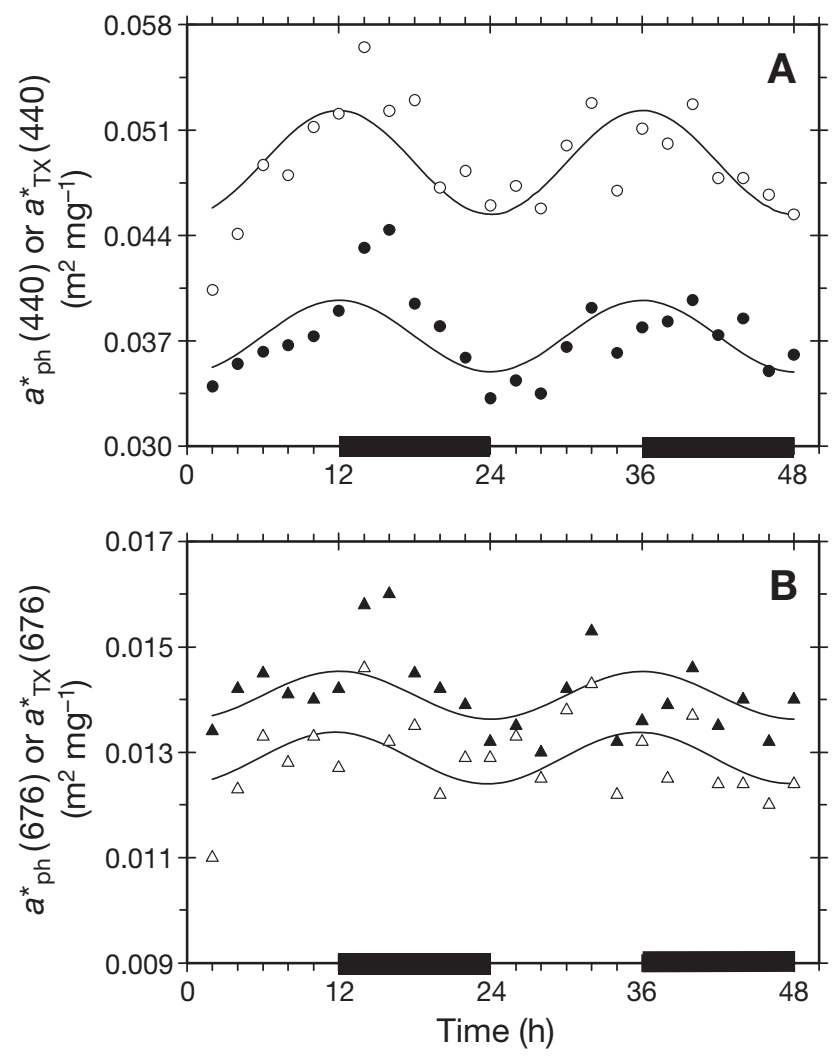

Fig. 2. Isochrysis galbana. Diel variations in chl a-specific absorption coefficients at (A) $440 \mathrm{~nm}, a^{*}{ }_{\mathrm{ph}}(440)(\bullet)$, or $a^{*}{ }_{\mathrm{ph}}(\lambda)$ after solubilization in $0.5 \%$ Triton X-100 at $440 \mathrm{~nm}, a^{*}{ }^{*}$ TX (440) (O), and (B) $a^{*}{ }_{\mathrm{ph}}(676)(\mathbf{\Lambda})$, or $a^{*}{ }_{\mathrm{TX}}(676)(\Delta)$. Curve represents cosine fit to data; black bars indicate dark periods 
Table 2. Isochrysis galbana. Chlorophyll a concentration [chl a], chl a-specific absorption coefficient $\left(a^{*}{ }_{\mathrm{ph}}[\lambda]\right), a^{*}{ }_{\mathrm{ph}}(\lambda)$ after solubilization in $0.5 \%$ Triton X-100 $\left(a^{*}{ }_{\mathrm{TX}}[\lambda]\right)$, reconstructed $a^{*}{ }_{\mathrm{ph}}(\lambda)\left(a^{*}{ }_{\text {rec }}[\lambda]\right)$, efficiency factor for absorption $\left(Q_{a}[\lambda]\right)$ and computed package effect index $\left(Q_{a}^{*}[\lambda]\right)$ at 440 and $676 \mathrm{~nm}$, intracellular chl a concentration $\left.\left(c_{\mathrm{chl}}\right)\right)$, mean cell diameter $(d)$, pigment ratios (chl $c$ : $\mathrm{chl} C_{1+2}$; fuco: fucoxanthin; DD: diadinoxanthin; DT: diatoxanthin) and reconstructed absorption ratios of pigments to total pigment at $440 \mathrm{~nm}$. Minimal and maximal values and magnitude of diel variation (\%) of parameters estimated using cosine fit to data, as in Eq. (9) are shown. Minus signs indicate decrease during light periods; $\mathrm{r}^{2}$ values are from linear regressions between all measured data and data estimated by Eq. (9)

\begin{tabular}{|c|c|c|c|c|}
\hline Parameter & Max. & Min. & $\%$ & $r^{2}$ \\
\hline$[\mathrm{chl} a]\left(\mathrm{mg} \mathrm{m}^{-3}\right)$ & 686 & 534 & -28.4 & 0.83 \\
\hline$a_{\mathrm{ph}}^{*}(440)\left(\mathrm{m}^{2} \mathrm{mg}^{-1}\right)$ & 0.0397 & 0.0350 & 13.6 & 0.40 \\
\hline$a_{\mathrm{ph}}^{*}(676)\left(\mathrm{m}^{2} \mathrm{mg}^{-1}\right)$ & 0.0145 & 0.0136 & 6.6 & 0.17 \\
\hline$a^{*} \mathrm{TX}(440)\left(\mathrm{m}^{2} \mathrm{mg}^{-1}\right)$ & 0.0523 & 0.0454 & 15.2 & 0.51 \\
\hline$a^{*} \mathrm{TX}(676)\left(\mathrm{m}^{2} \mathrm{mg}^{-1}\right)$ & 0.0134 & 0.0124 & 7.9 & 0.20 \\
\hline$a_{\text {rec }}^{*}(440)\left(\mathrm{m}^{2} \mathrm{mg}^{-1}\right)$ & 0.0414 & 0.0373 & 10.8 & 0.34 \\
\hline$a_{\text {rec }}^{*}(676)\left(\mathrm{m}^{2} \mathrm{mg}^{-1}\right)$ & 0.0126 & 0.0117 & 7.2 & 0.19 \\
\hline$Q_{a}(440)$ & 0.36 & 0.29 & 22.0 & 0.56 \\
\hline$Q_{a}(676)$ & 0.11 & 0.088 & 28.1 & 0.52 \\
\hline$Q_{a}{ }^{*}(440)$ & 0.82 & 0.79 & -3.9 & 0.32 \\
\hline$Q_{a}^{*}(676)$ & 0.95 & 0.93 & -1.5 & 0.51 \\
\hline$c_{\mathrm{chl} a} d\left(\mathrm{~kg} \mathrm{~m}^{-2}\right)$ & 13.8 & 11.0 & -26.1 & 0.17 \\
\hline$C_{\mathrm{chl} \mathrm{a}}\left(\mathrm{kg} \mathrm{m}^{-3}\right)$ & 3.1 & 2.3 & -32.5 & 0.17 \\
\hline$d\left(\times 10^{-6} \mathrm{~m}\right)$ & 4.8 & 4.5 & 7.7 & 0.75 \\
\hline $\operatorname{chl} c / \operatorname{chl~a}$ & 0.24 & 0.22 & 9.3 & 0.32 \\
\hline Fuco/chl a & 0.43 & 0.39 & 10.4 & 0.42 \\
\hline $\mathrm{DD}+\mathrm{DT} / \mathrm{chl} a$ & 0.25 & 0.20 & 24.1 & 0.46 \\
\hline$a_{\mathrm{chl} a} / a_{\text {total }}$ & 0.49 & 0.45 & -7.5 & 0.61 \\
\hline$a_{\text {chl } c} / a_{\text {total }}$ & 0.20 & 0.19 & 6.0 & 0.36 \\
\hline$a_{\mathrm{DD}+\mathrm{DT}} / a_{\text {total }}$ & 0.18 & 0.15 & 16.1 & 0.39 \\
\hline
\end{tabular}

The increase in $a^{*}{ }_{p h}(440)$ during the light periods was parallel to the increase in the $a_{\text {chlc }} / a_{\text {total }}$ ratio by $6.0 \%$ and the $a_{\mathrm{DD}+\mathrm{DT}} / a_{\text {to- }}$ tal ratio at $440 \mathrm{~nm}$ by $16 \%$, with decreases in the $a_{\text {chl }} / a_{\text {total }}$ ratio at $440 \mathrm{~nm}$ by $7.5 \%$ (Table 2). Distinct diel variations were not obtained for $a_{\text {fuco }}$ and $a_{\beta, \beta \text {-carotene }}$ to $a_{\text {total }}$ at $440 \mathrm{~nm}(\mathrm{p}>0.05)$. The coefficient of variation throughout a diel cycle was $3.1 \%$ for $a_{\text {fuco }}$ to $a_{\text {total }}$ at $440 \mathrm{~nm}$ and $5.9 \%$ for $a_{\beta, \beta \text {-carotene }}$ to $a_{\text {total }}$ at $440 \mathrm{~nm}$.

\section{DISCUSSION}

\section{Shift in phase of diel cycle of $a^{*}{ }_{p h}(\lambda)$}

The diel pattern in $a^{*}{ }_{\mathrm{ph}}(\lambda)$ under illumination that includes UVR was characterized by maxima toward the end of light periods and minima toward the start of light periods. However, an opposite diel pattern in $a^{*}{ }_{p h}(\lambda)$ for the same species Isochrysis galbana with maxima toward the end of dark periods and minima toward the end of light periods was observed under illumination comprised of PAR alone (500 $\mu \mathrm{mol}$ photons $\mathrm{m}^{-2} \mathrm{~s}^{-1}$ ) (Ohi et al. 2002), compared to that under illumination that included UVR (Fig. 5). These diel variation in $a^{*}{ }_{p h}(440)(-22 \%)$ was

toward the end of light periods and minima toward the end of dark periods ( $p<0.05)$ (Fig. 3). The increase in $a^{*}(440)$ or $a^{*}$ TX (440) during the light periods (Fig. 2) was parallel to an increase in the fucoxanthin/chl $a$ ratio by $10 \%$, the $\operatorname{chl} C_{1+2} / \mathrm{chl} a$ ratio by $9.3 \%$, and the (diadinoxanthin plus diatoxanthin)/chl a ratio by $24 \%$ (Table 2). A distinct diel variation was not observed for $\beta$, $\beta$-carotene/chl a $(p>0.05)$. The coefficient of variation throughout a diel cycle was $7.5 \%$ for $\beta, \beta$-carotene/chl a.

The relative ratio in reconstructed absorption of each pigment to total pigment was examined. The reconstructed absorption of $\mathrm{chl} a_{1} a_{\mathrm{chl} a}(440)$, to the reconstructed absorption of total pigment, $a_{\text {total }}(440)$, was from 45 to $49 \%$ throughout a diel cycle. The relative ratio of the various pigments to $a_{\text {total }}(440)$ was followed by fucoxanthin, diadinoxanthin plus diatoxanthin, chl $C_{1+2}$ and $\beta, \beta$-carotene, in that order. Distinct diel variations were observed for the ratios of $a_{\text {chlc }}$ or $a_{D D+D T}$ to $a_{\text {total }}$ at $440 \mathrm{~nm}$, with maxima toward the end of light periods and minima toward the end of dark periods ( $p$ $<0.001$ ) (Fig. 4). In contrast, a distinct diel variation was observed for the ratios of $a_{\mathrm{chl} \text { a }}$ to $a_{\text {total }}$ at $440 \mathrm{~nm}$, with a $12 \mathrm{~h}$ shift in the periodicity (p < 0.001) (Fig. 4). primarily caused by changes in cell size $(21 \%)$ due to a packaging effect under PAR alone. The present and previous results (Ohi et al. 2002) provide strong evidence that the same species of phytoplankton exhibits $12 \mathrm{~h}$ shifts in diel patterns of $a^{*}$ ph $(\lambda)$ depending on UVR. The diel pattern of $a^{*}{ }_{p h}(\lambda)$ under illumination that included UVR indicated a $6 \mathrm{~h}$ shift compared to the pattern of $1500 \mu \mathrm{mol}$ photons $\mathrm{m}^{-2} \mathrm{~s}^{-1} \mathrm{PAR}$ alone (Ohi et al. 2003) (Fig. 5). The diel variation in $a^{*}{ }_{\mathrm{ph}}$ (440) $(50 \%)$ was primarily caused by changes in pigmentation of photoprotective pigments under high irradiance.

\section{Reconstructed absorption coefficients and efficiency factors for absorption}

Distinct diel variations in reconstructed $a^{*}{ }_{\text {rec }}(\lambda)$ were also observed, with maxima toward the end of light periods and minima toward the end of dark periods ( $\mathrm{p}<0.01$ at $440 \mathrm{~nm}$ and $\mathrm{p}<0.05$ at $676 \mathrm{~nm}$ ) (Fig. 6). The relationship between diel variation in experimental $a^{*}{ }_{\mathrm{ph}}(440)$ and diel variation in reconstructed $a^{*}{ }_{\text {rec }}(440)$ was significantly correlated $(\mathrm{p}<0.001)$; the slope of the 

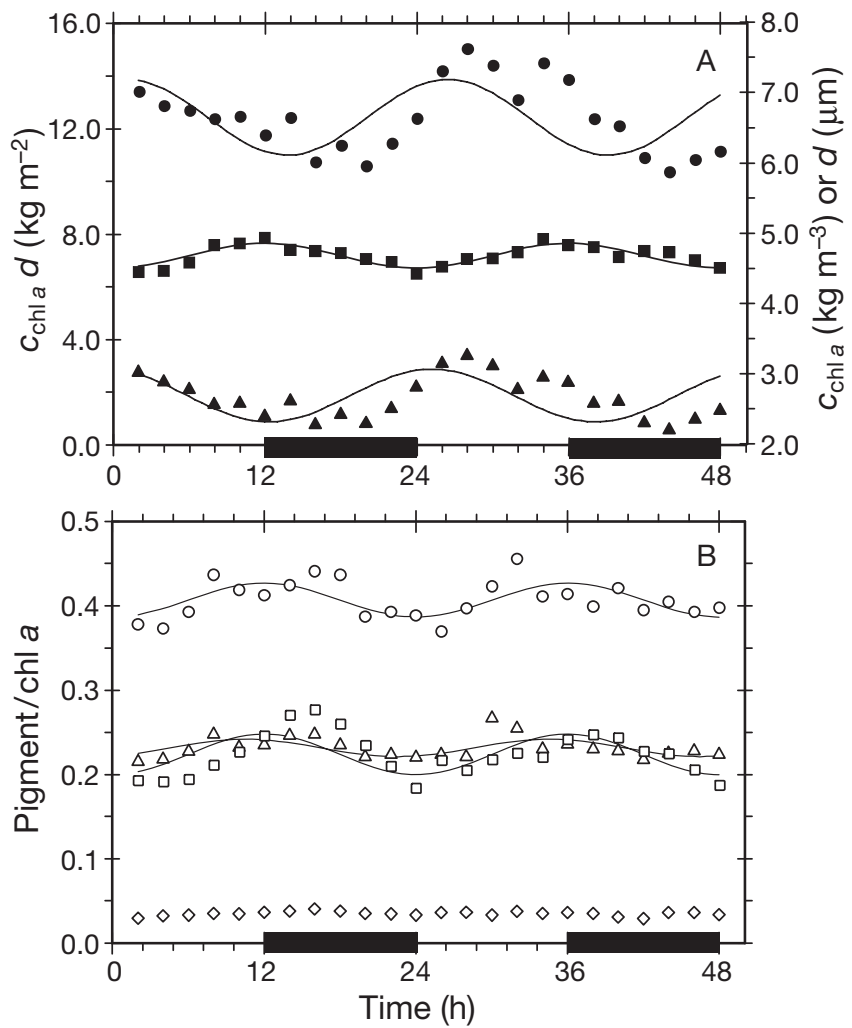

Fig. 3. Isochrysis galbana. Diel variations in (A) product of intracellular chlorophyll a concentration $\left(c_{\mathrm{chl}}\right.$ a) and cell diameter $(d)$ and $\left(c_{\mathrm{chl}}\right.$ ) or $d_{\text {, and }}$ (B) ratios of pigments to chl $a$.

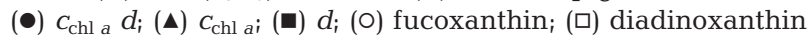
plus diatoxanthin; $(\Delta) \operatorname{chl} C_{1+2}(\diamond)$ and $\beta, \beta$-carotene. Curve represents cosine fit to data except for fucoxanthin and $\beta, \beta$-carotene; black bars indicate dark periods

regression line was 0.95 . The reconstructed values were lower than the measured values by an average of $5 \%$, although the reconstruction was fairly satisfactory. Therefore, this allows us to examine how the various parameters contributed to $a^{*}{ }_{\mathrm{ph}}(\lambda)$ variations over their diel cycle.

Distinct diel variations were observed for $Q_{a}(\lambda)$, with maxima toward the end of light periods and minima toward the end of dark periods ( $\mathrm{p}<0.01$ at 440 and $676 \mathrm{~nm}$ ) (Fig. 7). $Q_{a}(\lambda)$ ranged from 0.29 to 0.36 at $440 \mathrm{~nm}$, and from 0.11 to 0.088 at $676 \mathrm{~nm}$. For the range of $Q_{a}(\lambda)$ estimated, the $Q_{a}(\lambda)$ versus $\rho^{\prime}(\lambda)$ relationship (Eq. 4) was linear (see Fig. 1 in Morel \& Bricaud 1981). A quantitative evaluation of this effect can be made by computing the package-effect index $Q_{a}{ }^{*}(\lambda) . Q_{a}{ }^{*}(\lambda)$, which ranged from 1 (no package effect) to 0 (maximal package effect), was obtained using Eq. (7). Distinct, but gentle diel variations in $Q_{a}{ }^{*}(\lambda)$ were observed, with maxima toward the end of dark periods and minima toward the end of light periods ( $p<0.01$ at $440 \mathrm{~nm}$ and

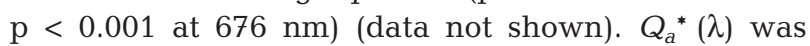
remarkably constant at $-3.9 \%$ for $440 \mathrm{~nm}$ and $-1.5 \%$

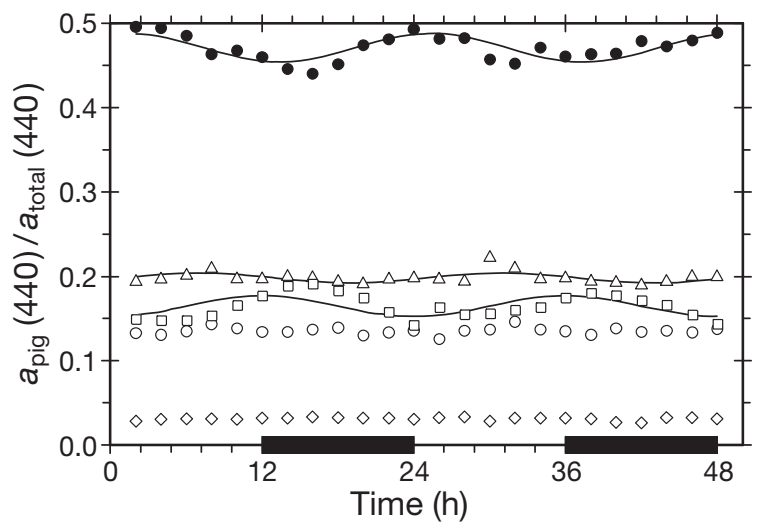

Fig. 4. Isochrysis galbana. Diel variations in reconstructed absorption ratios of pigments to total pigments, $a_{\text {pig }}(440) /$

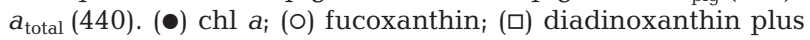
diatoxanthin; $(\Delta)$ chl $c_{1+2} ;(\diamond) \beta, \beta$-carotene. Curve represents cosine fit to data except for fucoxanthin and $\beta, \beta$-carotene; black bars indicate dark periods

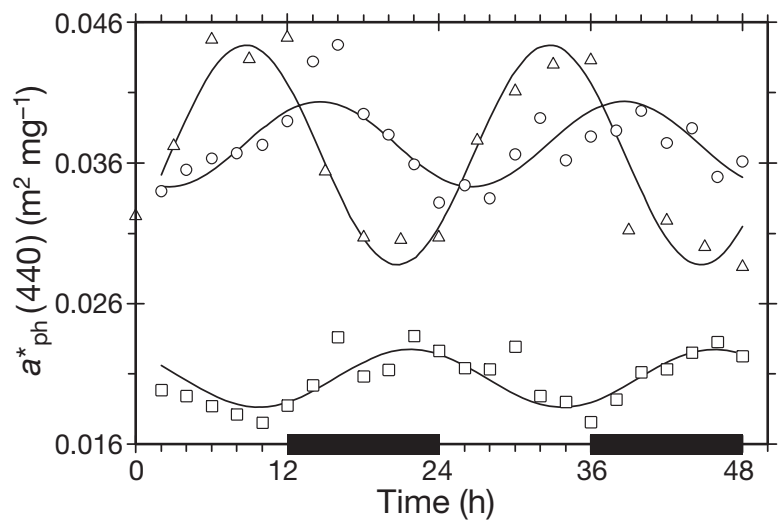

Fig. 5. Isochrysis galbana. Diel variations in chl a-specific absorption coefficients at $440 \mathrm{~nm}, a^{*}{ }_{\mathrm{ph}}(440)$, under (O) $500 \mu \mathrm{mol} \mathrm{m} \mathrm{m}^{-2} \mathrm{~s}^{-1}$ PAR that included UVR (present study), (ㅁ) $500 \mu \mathrm{mol} \mathrm{m} \mathrm{m}^{-2} \mathrm{~s}^{-1}$ of PAR alone (Ohi et al. 2002), and $(\Delta)$ $1500 \mu \mathrm{mol} \mathrm{m} \mathrm{m}^{-2} \mathrm{~s}^{-1}$ PAR alone (Ohi et al. 2003). Curve represents cosine fit to data; black bars indicate dark periods

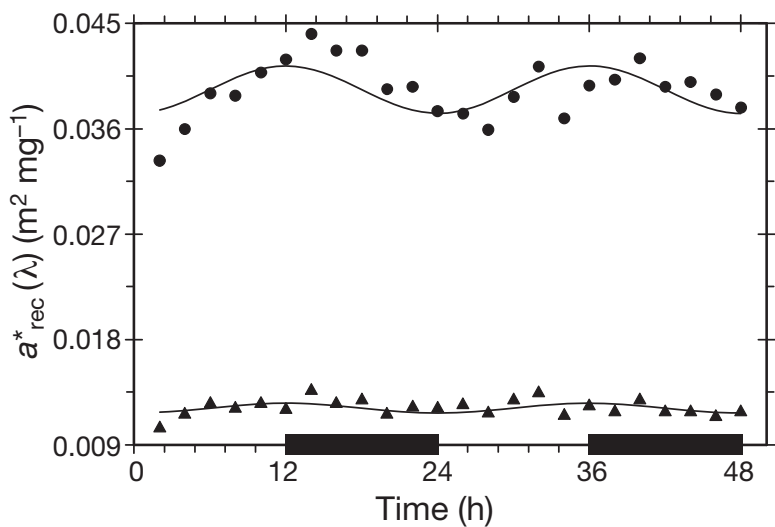

Fig. 6. Isochrysis galbana. Diel variations in reconstructed chl $a$-specific absorption coefficients $a^{*}{ }_{\text {rec }}(\lambda)$, at (•) 440 and (ム) $676 \mathrm{~nm}$. Curve represents cosine fit to data; black bars indicate dark periods 


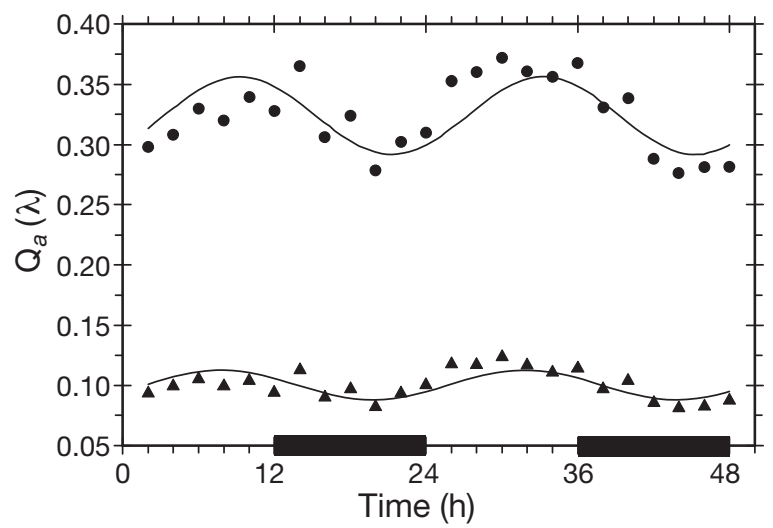

Fig. 7. Isochrysis galbana. Diel variations in reconstructed values of efficiency factor, $Q_{a}(\lambda)$, at (•) 440 and (४) $676 \mathrm{~nm}$. Curve represents cosine fit to data; black bars indicate dark periods

for $676 \mathrm{~nm}$ (Table 2). These variations in $Q_{a}{ }^{*}(\lambda)$ indicated negligible package effects.

$Q_{a}(\lambda)$ was estimated from the product of the intracellular chl a concentration $C_{\mathrm{chl}}{ }_{a}$, cell diameter $d_{\text {, and }} a^{*} \mathrm{TX}$ $(\lambda)$ (Eqs. 4 to 6). A distinct diel variation was observed for $a^{*} \mathrm{TX}(\lambda)$, with maxima toward the end of light periods and minima toward the end of dark periods, possibly due to photoacclimation $(\mathrm{p}<0.01$ at $440 \mathrm{~nm}$ and $\mathrm{p}<0.05$ at $676 \mathrm{~nm}$ ) (Fig. 2). Distinct diel variations were obtained for $c_{\mathrm{chl} a} d$, with a $12 \mathrm{~h}$ shift in periodicity ( $p<0.05$ ) (Fig. 3). Thus, a distinct diel variation was observed for $c_{\mathrm{chl}} d_{\text {, }}$, with maxima toward the end of dark periods and minima toward the end of light periods. However, a distinct but gentle diel variation was observed for $d$, with maxima toward the end of light periods and minima toward the end of dark periods $(p<0.05)$ (Fig. 3). Therefore, the main source of diel variation for $Q_{a}(\lambda)$ appears to be $a^{*} \mathrm{TX}(\lambda)$, which increased by $15 \%$ at $440 \mathrm{~nm}$ and $7.9 \%$ at $676 \mathrm{~nm}$ during the light periods (Fig. 2). $C_{\mathrm{chl}}{ }_{a} d$, which decreased by $26 \%$ during the light periods (Fig. 3), reduced the diel variation in $Q_{a}(\lambda)$ by dampening the effect of $c_{\mathrm{chl} a} d$ on $Q_{a}(\lambda)$. Any changes in $a^{*}{ }_{\mathrm{TX}}(\lambda)$ could have been due only to changes in the pigmentation, as described above.

\section{Contribution of pigmentation to diel variation in $a^{*}{ }_{p h}(\lambda)$}

We examined the contribution of pigmentation and its effect on the diel variation in $a^{*}{ }_{\mathrm{ph}}(440)$. An increase in pigmentation due to changes in the relative proportions of chl $a$ and accessory pigments during the light periods resulted from an increase in photoprotective pigments, especially the diadinoxanthin plus diatoxanthin to chl a ratio (Fig. 3). Similar results under a light:dark cycle at high-light irradiance have been observed for the photosynthetic and photoprotective pigment to chl a ratio (e.g. Kohata \& Watanabe 1989) and diadinoxanthin plus diatoxanthin to chl a ratio (e.g. Demers et al. 1991). The increase in $a^{*}{ }^{*}$ (440) during the light periods was due mainly to both an increase in $a_{\mathrm{DD}+\mathrm{DT}}(440)$ and a decrease in $a_{\mathrm{Chl} \mathrm{a}}(440)$ during the light periods over the diel cycle. The increase in $a^{*}{ }_{\mathrm{ph}}(440)$ during the light periods seemed to directly affect the amount of light energy absorbed.

\section{Implication for field observations}

The results of this study provide strong evidence that the $a^{*}{ }_{p h}(\lambda)$ can increase during the day under a diel cycle in the surface layer of the ocean exposed to UVR. Diel patterns in photosynthetic and photoprotective pigments due to photoadaptation were the primary cause of the diel pattern in $a^{*}{ }_{p h}(\lambda)$ under exposure to UVR. Since the diel patterns in pigmentation of Isochrysis galbana are similar to those of other phytoplankton species exposed to UVR, these results could be important for interpreting diel variations in optical properties of the ocean's surface-layer. The results presented here and published previously (Ohi et al. 2002) suggest that phytoplankton can exhibit $12 \mathrm{~h}$ shifts in diel patterns of $a^{*}{ }_{\mathrm{ph}}(\lambda)$ in the surface water-layer exposed to UVR. The measurement of light-depth dependent optical properties presents a new challenge for assessing the impact of this phenomenon on the procedures used for estimating phytoplankton biomass and production.

Acknowledgement. The manuscript was greatly improved by the comments of anonymous reviewers.

\section{LITERATURE CITED}

Babin M, Stramski D (2002) Light absorption by aquatic particles in the near-infrared spectral region. Limnol Oceanogr 47:911-915

Berner T, Dubinsky Z, Wyman K, Falkowski PG (1989) Photoadaptation and the 'package' effect in Dunaliella tertiolecta (Chlorophyceae). J Phycol 25:70-78

Caldwell MM (1971) Solar ultraviolet radiation and the growth and development of higher plants. In: Giese AC (ed) Photophysiology. Academic Press, New York, p 131-177

Demers S, Roy S, Gagnon R, Vignault C (1991) Rapid lightinduced changes in cell fluorescence and in xanthophyllcycle pigments of Alexandrium excavatum (Dinophyceae) and Thalassiosira pseudonana (Bacillariophyceae): a photo-protection mechanism. Mar Ecol Prog Ser 76: 185-193

Dickey T, Granata T, Hamilton M, Wiggert J, Marra J, Langdon C, Siegel DA (1990) Time series observations of bio- 
optical properties in the upper layer of the Sargasso Sea. Proc Int Soc Opt Eng Ocean Optics 10:202-213

DuRand MD, Olson RJ (1996) Contributions of phytoplankton light scattering and cell concentration changes to diel variations in beam attenuation in the equatorial Pacific from flow cytometric measurements of pico-, ultra- and nanoplankton. Deep-Sea Res II 43:891-906

DuRand MD, Olson RJ (1998) Diel patterns in optical properties of the chlorophyte Nannochloris sp.: relating individual-cell to bulk measurements. Limnol Oceanogr 43: $1107-1118$

Fujiki T, Taguchi S (2001) Relationship between light absorption and the xanthophyll-cycle pigments in marine diatoms. Plankton Biol Ecol 48:96-103

Gardner WD, Chung SP, Richardson MJ, Walsh ID (1995) The oceanic mixed-layer pump. Deep-Sea Res 42:757-775

Guillard RRL, Ryther JH (1962) Studies of marine planktonic diatoms. I. Cyclotella nana Hustedt and Detonula confervacea (Cleve) Gran. Can J Microbiol 8:229-239

Halberg F, Haus E, Scheving LE (1978) Sampling of biologic rhythms, chronocytokinetics and experimental oncology. In: Valleron AJ, Macdonald PDM (eds) Biomathematics and cell kinetics. Elsevier Biomedical Press, New York, p 175-190

Hamilton M, Granata TC, Dickey TD, Wiggert JD, Siegel DA, Marra J, Langdon C (1990) Diel variations of bio-optical properties in the Sargasso Sea. Proc Int Soc Opt Eng Ocean Optics 10 (1302):214-224

Head EJH, Horne PW (1993) Pigment transformation and vertical flux in an area of convergence in the North Atlantic. Deep-Sea Res II 40:329-346

Jones LW, Kok B (1966) Photoinhibition of chloroplast reactions. I. Kinetics and action spectra. Plant Physiol 41:1037-1043

Kieding N, Rudolph N, M?ller U (1984) Diurnal variation in influx and transition intensities in the $\mathrm{S}$ phase of hamster cheek pouch epithelium cells. In: Edmunds L Jr (ed) Cell cycle clocks. Marcel Dekker, New York, p 135-159

Kohata K, Watanabe M (1989) Diel changes in the composition of photosynthetic pigments and cellular carbon and nitrogen in Pyramimonas parkeae (Prasinophyceae). J Phycol 25:377-385

Kroon BMA, Latasa M, Ibelings BW, Mur LR (1992) The effect of dynamic light regimes on Chlorella. I. Pigments and cross sections. Hydrobiologia 238:71-78

Lesser MP (2000) Depth-dependent photoacclimatization to solar ultraviolet radiation in the Caribbean coral Montastraea faveolata. Mar Ecol Prog Ser 192:137-151

Lesser MP, Barry TM, Banaszak AT (2002) Effects of UV radiation on a chlorophyte alga (Scenedesmus sp.) isolated from the fumarole fields of Mt. Erebus, Antarctica. J Phycol 38:473-481

Editorial responsibility: Otto Kinne (Editor-in-Chief), Oldendorf/Luhe, Germany
Morel A, Bricaud A (1981) Theoretical results concerning light absorption in a discrete medium, and application to specific absorption of phytoplankton. Deep-Sea Res 28: 1375-1393

Ohi N, Ishiwata Y, Taguchi S (2002) Diel patterns in light absorption and absorption efficiency factors of Isochrysis galbana (Prymnesiophyceae). J Phycol 38:730-737

Ohi N, Shino M, Ishiwata Y, Taguchi S (2003) Light absorption of Isochrysis galbana (Prymnesiophyceae) under day-night cycle at high-light irradiance. Plankton Biol Ecol 50:1-9

Siegel DA, Dickey TD, Washburn L, Hamilton MK, Mitchell BG (1989) Optical determination of particulate abundance and production variations in the oligotrophic ocean. DeepSea Res 36:211-222

Smith RC, Baker KS (1979) Penetration of UV-B and biologically effective dose-rates in natural waters. Photochem Photobiol 29:311-323

Smith RC, Baker KS, Holm-Hansen O, Olson RS (1980) Photoinhibition of photosynthesis in natural waters. Photochem Photobiol 31:585-592

Sosik HM, Mitchell BG (1991) Absorption, fluorescence, and quantum yield for growth in nitrogen-limited Dunaliella tertiolecta. Limnol Oceanogr 36:910-921

Sosik HM, Mitchell BG (1994) The effects of temperature on growth, light absorption and quantum yield in Dunaliella tertiolecta (Chlorophyceae). J Phycol 30:833-840

Stelow RB (1974) The wavelength in sunlight effective in producing skin cancer: a theoritical analysis. Proc Natl Acad Sci USA 71:157-191

Stramska M, Dickey TD (1992) Variability of bio-optical properties of the upper ocean associated with diel cycles in phytoplankton populations. J Geophys Res 97:1787317887

Stramski D, Reynolds RA (1993) Diel variations in the optical properties of a marine diatom. Limnol Oceanogr 38: $1347-1364$

Stramski D, Shalapyorok A, Reynolds RA (1995) Optical characterization of the oceanic unicellular cyanobacterium Synechococcus grown under a day-night cycle in natural irradiance. J Geophys Res 100:13295-13307

Taira H, Goes JI, Gomes HR, Yabe K (2004) Photoinduction of mycosporine-like amino acids and cell volume increases by ultraviolet radiation in the marine dinoflagellate Scrippsiella sweeneyae. Plankton Biol Ecol 51: 82-94.

van de Hulst HC (1957) Light scattering by small particles. Wiley-Liss, New York

Zapata M, Garrido JL (1997) Occurrence of phytylated chlorophyll $c$ in Isochrysis galbana and Isochrysis sp. (clone T-ISO) (Prymnesiophyceae). J Phycol 33:209-214

Submitted: April 19, 2005; Accepted: December 8, 2005

Proofs received from author(s): June 20, 2006 